\title{
The Effect of Giving Aloe Vera Extract to Reduce the Vaginal Discharge on DMPA Contraceptive Injection Acceptors in the Working Area of Perumnas Antang Health Center, Makassar City
}

\author{
Rika Handayani ${ }^{1}$, Syamsuriyati ${ }^{2}$, Misrawati $^{3}$, Marliah $^{4}$, Hasbiah Wardani ${ }^{5}$, \\ Mirna $^{6}$, Nur Asmi ${ }^{7}$, Rahmat Haji Saeni ${ }^{8}$ \\ ${ }^{1-6}$ Faculty of Nursing and Midwifery, Megarezky University, Makassar, Indonesia \\ ${ }^{7,8}$ Department of Nutrition, Health Polytechnic, Ministry of Health, Mamuju, Indonesia
}

Corresponding Author: Rahmat Haji Saeni

DOI: https://doi.org/10.52403/ijrr.20220206

\begin{abstract}
Background: Vaginal discharge (Flour albus) is a vaginal discharge that is not blood and is accompanied by clinical manifestations of various infections, malignancies or reproductive benign tumors. This symptom does not cause mortality, but morbidity because it always wets the inside of a woman and can cause irritation and itching so it will interfere and reduce the comfort in every activity, especially the sexual activity. The causes of vaginal discharge are varied; one of them is the use of DMPA contraceptive injections. WHO has advised all countries to carry out the traditional medicine in the health sector, including the aloe vera plant.

Purpose: The purpose of this study is to determine the effect of administering aloe vera extract to reduce vaginal discharge on DMPA contraceptive injection acceptors.

Method: Quasi-experimental (Quasi Experiment) and using a Post-test Only Control Group Design as the research design. The sample size is 30 respondents and using purposive sampling as the sampling method.

Results: By using the chi square test, the value of $=0.002$ is smaller than the value of $=0.05$, so H1 is accepted, Ho is rejected.

Conclusion: There is an Effect of Giving Aloe Vera extract to reduce vaginal discharge on DMPA contraceptive injection acceptors in the Working Area of Perumnas Antang Health Center.
\end{abstract}

Keywords: Aloe vera Extract, Vaginal Discharge, and DMPA Injection

\section{INTRODUCTION}

Flour albus or commonly known as vaginal discharge is a vaginal discharge that is not blood and is a clinical manifestation of various infections, malignancies or benign reproductive tumors. This symptom does not cause mortality, but morbidity because it always wets the inside of a woman and can cause irritation and itching so it will interfere and reduce comfort in every activity, especially the sexual activity.

Normal vaginal discharge is usually colorless or clear, odorless, not excessive and does not cause complaints. Meanwhile, abnormal vaginal discharge is usually yellow or grayish green, has a fishy or foul smell, in large quantities and causes complaints such as itching and burning sensation in the intimate area[1]. The causes of vaginal discharge are varied, including fungi, bacteria, viruses and candid as, vaginal discharge experienced by inject able family planning acceptors is caused by the use of old inject able contraceptives, the influence of personal hygiene and the environment [2].

Studies show that candida vulvo vaginitis are the most frequently diagnosed among young women, about $15-30 \%$ of the 
symptoms of women who visit the doctor (Monalisa, 2016). According to Kissanti (2016) the incidence of vaginal discharge is mostly caused by candidiasis vulvovaginitis bacteria because many women do not know how to clean their vaginal area. Other causes are vaginitis bacterial and trichomonas vaginalis. In Indonesia, available data from women who experience vaginal discharge is difficult to obtain, this is understandable because only a few women have their reproductive organs checked [3].

WHO has advised countries to take advantage of the traditional medicine in the health sector. There are many things that can be done to reduce the occurrence of vaginal discharge, including pharmacological (medicine from a doctor), non-pharmacological such as: changes in behavior, personal hygiene, psychology and consuming herbal/natural products that are believed to have efficacy[4]. One of the natural treatments is Aloe vera. Aloe vera is a plant that has long been known in Indonesia because of its use as a medicine for various diseases. In addition, Aloe Vera is a Liliaceae plant that has many different species, of which only one species is commonly used as a medicinal plant since thousands of years ago [5].

Aloe vera is very useful and has a powerful effect because of its content, which is rich in nutrients, vitamins $\mathrm{C}$ and $\mathrm{E}$, 18 types of amino acids include aloin, carbohydrates, fats, water, vitamins, minerals, enzymes and hormones. All of them are natural antioxidants without side effects. Aloe vera also contains antiseptic, antiviral, anti-fungal, anti-cancer, antibacterial and anti-viral properties that are resistant to antibiotics. The results of previous studies have not found any side effects of using aloe vera. If there is a problem, it is usually an allergy in those who have never consumed aloe vera, but this reaction arises because of the aloe vera's ability to fight disease[6].

\section{MATERIALS AND METHODS}

The type of research used in this study is Quasi Experimental with Post-test Only Control Group Design [7]. In this design, both the experimental group and the control group are compared. The experimental class received treatment while the control class did not receive treatment. Then, at the specified time, the experimental group and the control group were measured. The comparison of results between the two groups shows the effect of the two treatments given. The inclusion and exclusion criteria for this study are:

\section{Inclusion Criteria}

1. Mothers who use DMPA contraceptive injections acceptors in the Working Area of Perumnas Antang Health Center, Makassar City.

2. Mothers with DMPA contraceptive injections acceptors who are willing to be respondents.

3. Mothers with DMPA contraceptive injections acceptors with 6 months minimum duration of using and willing to be respondents.

4. Mothers with DMPA contraceptive injections acceptors who are willing to consume Aloe vera extract.

5. Mother with vaginal discharge with physiological signs who reside in the Working Area of Perumnas Antang Health Center, Makassar City.

\section{Exclusion Criteria}

1. Mothers who use DMPA contraceptive injections acceptors who do not follow the rules of the study.

2. Mothers with DMPA contraceptive injections acceptors who are not willing to consume Aloe vera extract

\section{Statistical analysis}

This study uses a descriptive analytic statistical test using the Chi Square test. The analysis process uses a computerized system. 


\section{RESULTS}

Table 1: Distribution of Respondents Characteristics In the Working Area of PerumnasAntang Health Center Makassar City in 2020

\begin{tabular}{|l|c|c|}
\hline Characteristics of Respondents & n & \% \\
\hline Age Group (Years) & & \\
\hline $20-35$ & 26 & 87 \\
$>35$ & 4 & 13 \\
\hline Education & & \\
\hline Junior High School & 5 & 17 \\
Senior High School & 19 & 63 \\
Diploma III & 3 & 10 \\
Bachelor & 3 & 10 \\
\hline Occupation & & \\
\hline Housewives & 21 & 70 \\
Private & 3 & 10 \\
Honorary employee & 3 & 10 \\
civil servant & 3 & 10 \\
\hline
\end{tabular}

Based on table 1 , we can see that from 30 respondents, it shows that the largest age group of DMPA contraceptive injections acceptors of aged 20-35 years, consist of 26 people with a percentage $(86.7 \%)$ and respondents of aged $>35$ years consist of 4 respondents with a percentage $(13,3 \%)$. Based on the education level, the highest is Senior High School which consist of $19(63 \%)$ and the lowest are Diploma III and bachelor levels, which consist of 3 $(10 \%)$. Based on the occupations, the highest is the housewives which consist of $21(70 \%)$ and the lowest are private, honorary employee and civil servants which consist of $3(10 \%)$.

Table 2: Distribution of Respondents Based on the Provision
of Aloe Vera Extract and the Incidence of Vaginal Discharge
in the Working Area of PerumnasAntang Health Center,
Makassar City in 2020
\begin{tabular}{|l|c|c|}
\hline Characteristics of Respondents & Frequency & Percentage \\
\hline Provision of Aloe Vera Extract & & \\
\hline Yes & 15 & 50 \\
No & 15 & 50 \\
\hline Vaginal Discharge Occurrence & & \\
\hline Vaginal discharge & 22 & 73 \\
Novaginal discharge & 8 & 26 \\
\hline
\end{tabular}

Based on table 2, we can see that from 30 respondents, it showed that 15 people are given aloe vera extract with a percentage of $(50 \%)$, and 15 people are not given aloe vera extract with a percentage of (50\%). Respondents then examined after being given aloe vera extract, and it was found that the most respondents experienced vaginal discharge as many as 22 people with a percentage of $(73 \%)$ while respondents who did not experience vaginal discharge are 8 people with a percentage of $(26 \%)$.

Table 3: The Effect of Giving Aloe Vera Extract to Reduce the Vaginal DischargeOn DMPA Contraceptive Injection Acceptors in the Working Area of PerumnasAntang Health Center, Makassar City in 2020

\begin{tabular}{|c|c|c|c|c|c|c|c|}
\hline \multirow[t]{3}{*}{ Variable } & \multicolumn{4}{|c|}{ Vaginal Discharge Occurrence } & \multirow{2}{*}{\multicolumn{2}{|c|}{ Frekuency }} & \multirow{3}{*}{ P Value } \\
\hline & \multicolumn{2}{|c|}{ Yes } & \multicolumn{2}{|c|}{ No } & & & \\
\hline & (n) & $(\%)$ & (n) & $(\%)$ & (n) & $(\%)$ & \\
\hline Provision of Aloe Vera Extract & & & & & & & \\
\hline Given & 7 & 31 & 8 & 100 & 15 & 100 & 0.002 \\
\hline Not Given & 15 & 69 & 0 & 0 & 15 & 100 & \\
\hline
\end{tabular}

Based on table 3 above, it shows that of the 15 respondents who were given aloe vera extract, there are 7 respondents who have vaginal discharge with a percentage of $(31 \%)$ and 8 respondents who do not have vaginal discharge with a percentage of $(100 \%)$. Meanwhile, of 15 respondents in the control group who were not given aloe vera extract, there are 15 respondents who have vaginal discharge with a percentage of (69\%), and respondents who do not experience vaginal discharge as many as 0 respondents with a percentage of $(0 \%)$.

By testing with the use of the chisquare test, the value of $=0.002$ is smaller than the value of $=0.05$, then $\mathrm{H} 1$ is accepted and $\mathrm{Ho}$ is rejected. It can be concluded that there is an effect of giving aloe vera extract to reduce vaginal discharge in DMPA contraceptive injections acceptors in the Working Area of Perumnas Antang Health Center.

\section{DISCUSSION}

\section{The Effect of Giving Aloe Vera Extract to Reduce vaginal discharge in DMPA contraceptive injections acceptors}

Vaginal discharge is the type of disorder most frequently examined by some patients with RTI (Reproductive Tract Infections) who come to a number of paramedics. Vaginal discharge can be a normal condition (physiological) or as a sign of a disease (pathological)[8]. Mothers 
who experience vaginal discharge are advised to consume aloe vera extract in addition to herbal treatment. Aloe vera is also known to have many benefits, one of which is to reduce vaginal discharge. It is known that the saponins in aloe vera have an effect that can kill germs, while Anthraquinones and quinones act as antibiotics[9].

Based on the results of the study, it shows that of the 15 respondents who were given aloe vera extract, there are 7 respondents who have vaginal discharge with a percentage of $(31 \%)$ and those who do not have vaginal discharge as many as 8 respondents with a percentage of $(100 \%)$. Meanwhile, of the 15 respondents in the control group who were not given aloe vera extract, there are 15 respondents who experienced vaginal discharge with a percentage of $(69 \%)$ and respondents who do not experience vaginal discharge as many as 0 respondent with a percentage of $(0 \%)$. By testing with the use of the chisquare test, the value of $=0.002$ is smaller than the value of $=0.05$, then $\mathrm{H} 1$ is accepted and Ho is rejected. It can be concluded that there is an effect of giving aloe vera extract to reduce vaginal discharge in DMPA contraceptive injections acceptors in the Working Area of PerumnasAntang Health Center.

This study is in line with research conducted by Ana Septiani (2017) with the title of giving aloe vera gel to reduce vaginal discharge in IUD family planning acceptors with the results of the study shows that: participant I experienced vaginal discharge reduced from 6 points to 3 points where the vaginal discharge did not come out much and not thick, participant II experienced reduced vaginal discharge from 6 points to 3 points where the vaginal discharge did not come out much, not thick, and not sticky, participant III experienced reduced vaginal discharge from 7 points to 4 points where the vaginal discharge did not come out much, not thick, and not sticky. With the conclusion showing that contraceptive injections who experience vaginal discharge are proven to be able to reduce their vaginal discharge after consuming aloe vera jelly[10].

This research is in line with research conducted by FeiziahHuslina (2017) which says that the benefits of aloe vera leaf extract can suppress fungal growth in vitro. The greater the concentration of aloe vera extract given, the greater the growth inhibition zone of C. albicans formed. Extract concentrations of $100 \%, 50 \%$ and $25 \%$, respectively, had inhibitory properties equivalent to $0.50 \mathrm{mg}, 0.24 \mathrm{mg}, 0.20 \mathrm{mg}$ of the antibiotic nystatin[11].

This study is in line with research conducted by WulanMargiana (2017) which said that aloe vera pudding can reduce vaginal discharge in women of childbearing age with the results of $=0.001$ which means that there is an effect of giving aloe vera pudding to women of childbearing age who experience vaginal discharge[12], [13].

\section{CONCLUSION}

Based on the results of the statistical test, the value of $=0.002$ is smaller than the value of $=0.05$, then $\mathrm{H} 1$ is accepted and Ho is rejected. So it can be concluded that there is an effect of giving aloe vera extract to reduce vaginal discharge in DMPA contraceptive injections acceptors.

\section{Acknowledgement: None}

Conflict of Interest: None

Source of Funding: None

Ethical Approval: Approved

\section{REFERENCES}

1. WHO, Report on global sexually transmitted infection surveillance, vol. 70, no. Supplement. 2018.

2. Manuaba, Memahami Kesehatan reproduksi Wanita. Jakarta: Arcan, 2008.

3. Andhita, Penyakit Wanita Yang Mematikan. Yogyakarta: Buana Pustaka, 2011.

4. R. Benson, Buku Saku Obstetrik dan Ginekologi. Jakarta: EGC, 2008.

5. Clayton, Keputihan dan Jamur Kandida Lain. Jakarta: EGC, 2010. 
6. Yulianto, Sejuta Khasiat Lidah Buaya. Yogyakarta: Pustaka baru Diantara, 2012.

7. S. Sastroasmoro and S. Ismael, Dasar-dasar Metodologi Penelitian Klinis, 3rd ed. Jakarta: Sagung Seto, 2010.

8. P. Sumudrika Ilankoon, C. Evangeline Goonewardena, R. Fernandopulle, and P. Rasika Perera, "Women's understanding and cultural practices related to vaginal discharge: A qualitative study," Nurs. Midwifery Stud., vol. 7, no. 2, p. 74, 2018, doi: 10.4103/nms.nms_60_17.

9. H. Marzanna and K. Dziedzic, "Aloe vera (L.) Webb.: Natural Sources of Antioxidants-A Review Marzanna," Plant Foods Hum. Nutr., vol. 74, pp. 255-265, 2019.

10. Septiani, "Pemberian Agar-agar Lidah Buaya Untuk Mengurangi Keputihan Pada Akseptor KB IUD."

11. F. Huslina, "Pengaruh Ekstrak Daun Lidah Buaya Terhadap Pertumbuhan Jamur
Candida Albicans Secara In Vitro,” J. Biot. Fak. Sains Dan Teknol., 2017.

12. E. Dirrahayu, I. P. Ramadhanti, and K. Lubis, "Aloe Vera Gel (Aloe Barbadensisi Miller) Alleviate Pathologic Vaginal Discharge," no. December, 2021, doi: 10.2991/ ahsr.k.211026.041.

13. S. Ishaque, A. Arshad, M. Haider, and F. Fatima, "Biological and Clinical Sciences Research Journal," Biol. Clin. Sci. Res. J., vol. 2020, no. 49, pp. 1-9, 2021.

How to cite this article: Rika Handayani, Syamsuriyati, Misrawati et.al. The effect of giving aloe vera extract to reduce the vaginal discharge on DMPA contraceptive injection acceptors in the working area of Perumnas Antang Health Center, Makassar City. International Journal of Research and Review. 2022; 9(2): 28-32. DOI: https://doi.org/10. 52403/ijrr.20220206 